\title{
Using the Bible in post-apartheid South Africa: Its influence and impact amidst the gay debate ${ }^{1}$
}

\author{
Jeremy Punt \\ University of Stellenbosch
}

\begin{abstract}
The Bible has generated a significant reception history in the first decade of democratic, post-apartheid South Africa. Its reception history testifies to how the Bible was considered to be important across a broad spectrum of society, also contributing to believers' lives and sense of self amidst the enormous changes in the country. Recent documents and decisions of the Dutch Reformed Church on homosexuality and the ensuing debates, highlight the influence and impact of Bible use in South Africa today. Examining different hermeneutical approaches to the Bible and using insights from reception theory, a number of interesting trends in the ongoing use and influence of the Bible are highlighted and discussed.
\end{abstract}

\section{INTRODUCTION}

Political leaders found the Bible to be a superbly useful ally in the establishment and maintenance of Apartheid South Africa during the latter part of the first half of the twentieth century, and in fact referenced biblical texts in their attempts to justify racial segregation (e g Dube 2000:6). Even before this time, policies which assumed the superiority of white colonists racially, religiously, morally, and otherwise - often included references to the Bible, accompanied by claims that their practices did justice to biblical "directives"2 (e g Dube 2000:5-6). In short, the impact of the Bible on the design and practice of the social engineering of Apartheid South Africa can hardly be overestimated.

\footnotetext{
${ }^{1}$ Edited version of a paper read at the Annual SBL Meeting in Philadelphia, PA, November 2005.

${ }^{2}$ During the colonial period, no essential difference was perceived between the missionary's roles of being "an agent of a political empire, a representative of civilization, and an envoy of God" (Mudimbe 1988:47).
} 
While antipathy towards the Bible would have been expected, the Bible is - ironically - still found to play an important role informing not only ecclesial practice but also social discernment on a wider scale. Accounting for the continuing influence and impact of the Bible in post-Apartheid South Africa, ${ }^{3}$ reference can be made to the constituency and demographic make-up of South Africa. It is a country characterised by complexity as much as by divisions, but also a country whose religious fibre have not changed much since democracy, and with communities of faith and Christianity, in particular as the majority religion, contributing variously to the broader society or public domain as well.

In this contribution on the use and impact of the Bible ${ }^{4}$ in postApartheid South Africa attention is focused on the current debate about gays (used here in the broad sense of the whole LGBT community) in the Dutch Reformed Church (DRC) in South Africa. ${ }^{5}$ After a brief evaluation of the use and impact of the Bible and the New Testament in particular in post-Apartheid South Africa, ${ }^{6}$ a reception studies perspective is introduced. In a third part of the paper and against this background, the use of Scripture in some recent, official documents of the DRC on homosexuality is evaluated. ${ }^{7}$

\footnotetext{
${ }^{3}$ For the role and impact of the church in post-Apartheid South Africa, cf Smit (2004:128-149).

${ }^{4}$ The focus in this presentation will be on the New Testament rather than the whole Bible, although the claims made for the use of the New Testament are generally valid for the Old Testament/Hebrew Bible as well.

${ }^{5}$ The similarity in using the Bible to structure ecclesial practice and by implication (sectors of) society - since the DRC holds the highest membership among white, Afrikaans-speaking people - in Apartheid times and in the current gay-debate in South Africa, has not gone unnoticed. "The claim for the moral superiority of heterosexuality is analogous to the way the leaders of the Dutch Reformed Church defended white superiority during the Apartheid era in South Africa" (Tatchell 2000:2). For the relationship between race and sexual categories to describe otherness, cf e.g. Stone (1997:36-41); Zack (1997).

${ }^{6}$ Distinguishing between academic settings and communities of faith, between which the ever-present gap probably grew somewhat during the last decade, is helpful while generalisations and oversimplifications should be avoided. However, given the involvement of many SA biblical scholars in the church, a fair amount of "academic" influence is still exerted in communities of faith and beyond - where appropriate, I will distinguish between academic and ecclesial contexts.

${ }^{7}$ The focus on the reception of the Bible in post-Apartheid SA, and in particular the DRC's appropriation of the Bible (NT) in the gay-debate, is deliberately narrow while cognisant of its social location within a larger discourse in SA and even beyond. Only developments until the end of October 2005 are considered.
} 


\section{STRUGGLING WITH THE BIBLE IN POST-"STRUGGLE" SOUTH AFRICA?}

Notwithstanding its use and abuse by the architects of Apartheid and its later supporters, the Bible continues to play a positive role in post-Apartheid South Africa, even if its interpretation is often contested. And indeed, apprehension and disillusionment do exist among some regarding the texts' ability to play a constructive public role - in no small way because of the legacy of the past, inter alia colonialism and Apartheid - and remaining difficulties and ambiguities around certain texts, interpretative practices and the tension between academic guild(s) and faith communities should not be slighted. ${ }^{8}$ However, through these communities of faith but also beyond them and their effect on public society, the Bible at times assumes a significant and important influence.

\subsection{A framework for analysing changing patterns in biblical hermeneutics}

A particularly useful way to describe and analyse the ongoing shifts - and impasses - in the use of the Bible in South Africa, is the taxonomy of Schüssler Fiorenza (1999:31-55) since it provides a useful framework ${ }^{9}$ for plotting and analysing also local biblical reception. ${ }^{10}$ The first of four is a doctrinal-fundamentalist paradigm which consists of a conservative approach to the Bible, viewing it as sacred Scripture that was divinely revealed. It employs a literalist reading intolerant of the scrutiny of the text's sociohistorical context or the social location of the contemporary interpreters - at

\footnotetext{
${ }^{8}$ Cf Punt (1998b:265-310) on the position of scholars such as Banana, Mofokeng, Maluleke and others.
}

${ }^{9}$ Other frameworks could also be useful, such as the distinction between premodern, modern and postmodern interpretation (cf Thiselton 2004:148ff), and here where the focus is on biblical reception, the three worlds of the text (cf Schneiders 1991; etc). On the other hand, whereas the latter methodologies tend to concentrate on the focus of the input (exegetical methodology) to gather interpretative results, the framework I choose to employ here allows for considering the production of the results as well as their impact in real life. This framework focuses less starkly on the different models of reading and criticism of the Bible that characterise the academy, church and society, making it possible to look at the use of the Bible across these publics yet without claiming that they operate exegetically in a similar mode. However, this taxonomy should not be perceived of as either linear or uni-directional even if the order in the discussion below may seem to suggest as much.

\footnotetext{
${ }^{10}$ Schüssler Fiorenza (1999:38-39) holds that while disciplinary paradigms may at times overlap and cross-pollinate each other, "theoretical frameworks of perspectives" such as religious dogmaticism, historical positivism, cultural relativism and emancipatory theoretical commitment cannot be "married promiscuously with each other without losing one's theoretical and practical footing". In the S A context, it was however the religious dogmaticism and historical paradigms which at times intersected with one another; but this is a topic for another discussion.
} 


\section{Using the Bible in post-apartheid South Africa}

times insisting on the unalterable status of the interpretations too, claiming their approximation to the status of revelation. In a world characterised by complexity and change, it is a potentially attractive paradigm since it delineates exclusivist group boundaries and clear-cut identities with the accompanying allure of emotional stability as well as religious security and certainty of faith. "Literalist fundamentalism vehemently rejects modern religious tolerance and pluralism but insists that the biblical message proclaims universal moral values and truth" (Schüssler Fiorenza 1999:40). However, the different and in the South African context, often contrasting ways in which Christian communities and churches appropriate the Bible, are concealed. ${ }^{11}$

While the doctrinal-fundamentalist paradigm reigned supreme also in Apartheid's heyday, both in support of the regime and the struggle against it, 12 the beginnings of a shift in the academy towards a scientific paradigm can be detected already since the 1980's. A scientist paradigm started to blossom, rooted in "the individualistic and relativistic discourses of modernity", and sharing "with fundamentalism a positivist and technological ethos"13 (Schüssler Fiorenza 1999:42). In a "scientific" positivist paradigm the emphasis is on value-free inquiry, appeals are made to the notion of a historical gap between past and present, all of which are couched in and focused on the universal applicability of the interpretation underwritten by the notion of a single, correct meaning of a text (Schüssler Fiorenza 1999:41). Rather than espousing a particular theological position, the rhetoric of scientific, disinterested objectivity rejected any recourse to conscious religious, socio-political or theological engagement as unscientific. In South Africa the emphasis shifted to methodology as can be seen in the overwhelming focus on hermeneutical methods (cf Punt 1998a) during the particularly stormy period of the dying years of Apartheid South Africa.

It was feminist and liberation theological interpretation in particular that contributed to the emergence of a (post-)modern hermeneutical or cultural paradigm in the last decade in biblical studies. Destabilising (to some extent)

\footnotetext{
${ }^{11}$ Ironically, while "colonialist biblicism" stands in stark contrast to "modern liberal religion", it shares with it the notion of recreating inside the religious world all which is not viable in the world: "a modernist integrative meaning system" (Schüssler Fiorenza 1999:41).

${ }^{12}$ But as for the use of the Bible, the irony was that the hermeneutical approach seldom differed in those who supported and defended Apartheid as well as by its opponents in the struggle against Apartheid.

13 "By objectifying, antiquating, reifying, and privatizing biblical Scriptures, it is in danger of playing into the hands of fundamental biblicism, which also claim that it can identify with certainty the univocal Word of $G^{\star} d[s i c]$ in the Bible as a provable fact" (Schüssler Fiorenza 1999:42).
} 
the positivist scientific ethos of the field through its rhetorical and practical force, the cultural relativist paradigm "underscores the rhetoricity of historical knowledge, symbolic power, and the multidimensional character of texts" (Schüssler Fiorenza 1999:43). Challenging notions such as that texts represent divine revelation or act as windows on historical realities, and rejecting a correspondence theory of truth, it insists that texts are "perspectival discourses constructing a range of symbolic universes". However, while the postmodern hermeneutics paradigm subverts the scientist approach with claims to certainty, it still exudes its "own scientific value-neutral and a theological character", often relishing "a playful proliferation of textual meaning" and failing to "address the increasing insecurities of globalized inequality" (Schüssler Fiorenza 1999:43). This paradigm has passed the South African landscape largely by without much influence, ${ }^{14}$ probably because the former two paradigms were so tightly in place.

However, a fourth paradigm is slowly emerging in the South African academy also, even if is yet to show its potential in most ecclesial communities and hardly posing a major challenge or destabilising the first two paradigms. Seeking "to redefine the self-understanding of biblical scholarship in ethical, rhetorical, political, cultural, emancipatory terms" and the scholar's role as socially engaged, transformative figure, a rhetorical-emancipatory paradigm views "biblical texts as rhetorical discourses that must be investigated as to their persuasive power and argumentative functions in particular historical and cultural situations" (Schüssler Fiorenza 1999:44). The emphasis on biblical scholarship's public character and socio-political responsibility goes beyond role-location, informing historical (re)constructions as much as contemporary interpretation of texts. ${ }^{15}$ The emancipatory paradigm requires a critical socio-political interpretation of the Bible, "[s]ince language not only creates a polysemy of meaning but also transmits values and re-inscribes social systems and semantic patterns of behaviour" (Schüssler Fiorenza 1999:46).

This useful taxonomy assists in evaluating the broader landscape of engagement with the Bible in South Africa, providing evidence of shifts that have taken place in the academy, if not always to the same extent in the church. The tenacity of the dogmatic-fundamentalist and the scientific

\footnotetext{
${ }^{14}$ With, probably, the exception being the influence generated by rhetorical critical studies (cf Vorster 1997:389-411; and others).

${ }^{15}$ The "Enlightenment's notion of the universal transcendental subject as the disembodied voice of reason" is undermined, as well as the postmodern insistence on dispensing with the subject and the impossibility of "knowing the world differently" (Schüssler Fiorenza 1999:46).
} 
positivist paradigms in South African biblical hermeneutics requires some more attention.

\subsection{A scientist approach amidst shifts in South African biblical hermeneutics}

Until fairly recently and at least until the 1990's, South African New Testament scholarship largely mirrored the local academy as elitist and populated by white males. The Apartheid system was not only legitimated by missiologists who followed Warneck, but also systematic theologians (such as the neoKuyperians like J D du Toit and F J M Potgieter) and biblical scholars (e g Groenewald and Snyman), keen to provide biblical and theological justification for racially separate churches and a political system of separation (Apartheid) (cf Cloete 2003:276; Naude 2005:12; Vorster 1983:94-111). The doctrinalfundamentalist paradigm played an important role in these developments, complete with appeals to biblical interpretations assuming the status of divine revelation.

While South African biblical scholarship has mostly proceeded beyond a doctrinal-fundamentalist paradigm during the last decade or two, its entanglement in a scientist, positivist paradigm is evident. ${ }^{16}$ Evaluating New Testament studies in terms of responsiveness at epistemological (knowledge), social and political levels, the systematic theologian Naude recently concluded that scholars still need to make their implicit epistemological assumptions explicit and to commit themselves to emancipatory cognitive interests (Habermas) enacted through self-reflection and ideology critique. ${ }^{17} \mathrm{He}$ also challenged South African New Testament scholars for what he perceived as their neglect of matters ethical, and especially a deficit regarding work on the ethics of interpretation, which is of particular significance in the South African context. Using three elements of public theology ${ }^{18}$ as his criteria, Naude found the voice of New Testament scholarship to be silent amidst public concerns about moral identity in a transitional society, retributive justice issues such as affirmative action and land distribution in South Africa, and the HIVIAIDS

\footnotetext{
${ }^{16}$ Earlier in 2005 at the annual meeting of the New Testament Society of South Africa, his keynote address provided an "outsider perspective on South African New Testament scholarship" based on the last decade's work in the Society's journal, Neotestamentica (Naude 2005). One can indeed argue, as Naude (2005:8 n16), also admits that it is a somewhat limited survey and prone to distort the findings. Nevertheless, certain interesting trends do emerge from his analysis.

${ }^{17}$ But with this Naude's assessment to some extent also gets caught up in the scientist paradigm, as his reference to Habermas who champions the notion of liberating hermeneutics from the constraints of selfhood (Thiselton 2004:147) for example underlines.

${ }^{18}$ Viz. open argumentation, accessible forms of communication and a focus on current public issues (Cady, in Naude 2005:10).
} 
pandemic (Naude 2005:11). ${ }^{19}$ The accusation levelled at the (biblical) scholarly community is therefore that it is not yet engaging society to the extent that is necessary, especially in a young democracy such as South Africa.

These observations gain special significance in the African setting, and given the involvement of the broader society with the Bible. African biblical hermeneutics are often argued to be characterised by a threefold set of interests, showing a predilection for historical and sociological matters ${ }^{20}$ (cf Gottwald 2000:91), with some attention reserved for thematic and symbolic dimensions of the text, as well as literary ${ }^{21}$ interpretative interests (West 2004:166). ${ }^{22}$ However, whether these should be conceived of as neat divisions or rather as focal points in an otherwise messy discourse and practice of biblical interpretation is another question. Claims about the "dominance" of African biblical interpretation ${ }^{23}$ by "socio-historical interpretative interests" and that its distinctiveness is situated in "the life interests that African interpreters bring to the text and how these life interests interact with their (predominantly socio-historical) interpretative interests"

\footnotetext{
${ }^{19}$ New Testament scholars' discomfort with involvement in what may be perceived as systematic theological concerns, and privileging autonomy and academic freedom along with a "scientist ethos, positivist orientation and mere interpretative knowledge", contributed to their continuing absence from the public sphere (Naude 2005:13-14).

${ }^{20}$ Three reasons are offered for the predominance of historical and sociological interests in African biblical interpretation: the training African scholars received in the Northern hemisphere where these methods were in vogue; such interests allow for attention to religious and cultural contexts underlying texts; and, a hermeneutic of suspicion is necessarily interested in the layered construction of texts and the subsequent discourses (West 2004:166).

${ }^{21}$ The accuracy of assigning literary approaches to "White Afrikaner structuralist interpretation" as well as the failure to unpack these terms for the diversity and complexity they inevitably contain makes this claim suspect.

${ }^{22}$ Earlier West (1991:237-238, n191) claimed that his understanding of "the world in front of the text" as particular reading strategy is built upon the views of Schneiders (1989:3-10, drawing on the work of Gadamer and Ricoeur and emphasising "distanciation") who developed this reading strategy in order to have an "oppressive text function liberatively". Advocating a "hermeneutics of transformation", the world created by the text and projected ahead of it is "appropriated" by means of "a kind of deconstituting of the self and reconstitution of the self according to the coordinates of the world of the text".

${ }^{23}$ Like African Christianity (West 2004:176), African biblical interpretation - probably as much in "pre-colonial" as in postcolonial times - is an equally broad term, of which the singularity may hide much complexity and various diverse positions, allowing them to go unacknowledged.
} 
(West 2004:167) might not adequately deal with the hybrid, pastiche-nature of such hermeneutical patterns. ${ }^{24}$

In the end, the ongoing impact of the Bible on South African society can hardly be denied, even if it may at times be uneasy and varying. Identifying specific hermeneutical or interpretative paradigms is important, but especially in a context such as South Africa with its rich if not always wholesome history of biblical reception, attention for the role of reception - the world in front of the text - is at least of equal importance.

\section{TEXTUAL RECEPTION: INFLUENCE AND IMPACT}

The Bible is not a neutral text, and neither have its various interactions with society been neutral; in fact, the Bible remains a deeply contested document, used in many different social struggles (e g Germond 1997:190). And therefore, "[i]f biblical scholarship is more than history and philology, it must take account of the context of the Bible, not only the original Sitz im Leben, but also its continuing 'contextualisation' in the religious communities that have preserved it and for whom it makes sense" (Sawyer 1990:319). Not only the biblical texts but also the traditions of their interpretation need to be considered when the impact of texts and accompanying hermeneutical practice(s) are investigated. In short, reading is influenced by traditions of interpretation as well as generating and contributing to the reading traditions.

Considering the impact and influence of the Bible from the perspective of the "world in front of the text" implies at least two aspects. Firstly, the traditions lying behind and leading to the formation of the text in its current form, or the tradition of interpretation has to be investigated. The relationship between the formation of the text and its interpretation by the communities of faith has been summarised by the claim that as much as there cannot be a church without the Bible, there cannot be a Bible without the church: ${ }^{25}$ "the church ... received the

\footnotetext{
${ }^{24}$ The focus on social and historical matters might not so much be unique to South Africa, as it is typical of the "ordinary" reading of the Bible as found in communities of faith across the world - the particular foci of interest in Africa might, however, be different, as well as the level of existential experience contributed to and gathered from such interaction with the Bible.

${ }^{25}$ The close link between (history of) the church and (the interpretation of) the Bible was perhaps best expressed by Gerhard Ebeling: the history of the Church can be seen as the history of the interpretation of the Bible, especially the "extremely complicated history of a self-interpreting and an interpreted Bible" (quoted in Froehlich 1991a:7, cf n 4; 8; so also Barth, quoted in Froehlich 1991b:343; Luz 1994:16-17). For criticism of Ebeling's thesis, cf Froehlich (1991a:11-12); Räisänen (1992:309, 309 n 18) argues that whereas Ebeling, in view of the connection with the interpretation of Bible, understands church history as a "prescriptive discipline", Räisänen rather opts for the "effective history" of the Bible as "empirical-historical task".
} 
apostolic witness, selected the canon, and gave the biblical witness unity by its interpretation" (Froehlich 1991a:7). ${ }^{26}$

But it is the second aspect of the world in front of the text which is sharply in focus in this paper, and requiring study of the contemporary setting of reception with everything this entails, ${ }^{27}$ such as social location, ideological stance and various other elements. Accounting for the relationship and interaction between literary and general history, Hans Robert Jauss, a student of Gadamer, described the effect of literature on society, or the "socially formative function of literature". Each successive reading of a text contributes to the shaping of a horizon of expectation which subsequent readers bring to the text and thereby influences its understanding (Jauss 1982:40; 142ff). ${ }^{28}$ This notion allows the literary text to assume an active role in its reception, "calling into question and altering social conventions through both content and form" (Holub 1984:68).

The value of the text's history of effects for its current interpretation emerges in a twofold relationship: the texts themselves are the product of a history of effects and the texts are accompanied by a history of effects constituted by the various ways and forms of interpretations made by the Church through the centuries (Luz 1994:23). On the one hand then, it must be realised that texts "are not the ultimate point of departure nor the ultimate authority but products of human reception, human experiences, and human history", and therefore secondary to the encounter between people and the divine. On the other hand, the biblical texts have a history of effects which cannot be detached from the texts, because it is an expression of the power and significance of the texts. In fact, the effects can often not be separated from

\footnotetext{
${ }^{26}$ Burrows and Rorem (1991:xii) argue that the need to study the "living histories" of biblical texts "insofar as their reception in communities shapes their common life" is a corollary of the historical critical efforts - especially as found in form and redaction studies - to establish and describe the pre-canonical histories of texts. Source Criticism and Traditionsgeschichte also serve as examples of the study of the reception of biblical texts - however, the aim(s) of such historical critical approaches differed, sometimes vastly, from today's reception studies (cf Chilton 1995:37-60).

${ }^{27}$ One of the biggest assets of receptions aesthetics is probably its insistence on a theory of literary communication in an interdisciplinary context, including the contributions made by "linguistics, semiotics, sociology, anthropology, philosophy and even biology". This implies that the School of Constance and Jauss' horizon of study expanded "from a theory of reception and effect of literature based on the science of the text to a theory of literary communication", inclusive of other disciplines (McKnight 1985:78).

${ }^{28}$ Accounting for this link, Jauss also proposed that the difference between a literary event and a historical occurrence is situated in the latter's continuing influence whereas a literary work needs to be "actualised' by contemporary readers. In a later writing, he contends that the distinction is situated in literary documents' ability to reach beyond its period of production. Both these arguments are easily refuted (cf Holub 1984:67-68).
} 
the texts because of the difficulties in determining where the texts end and the effects begin.

In fact, the interpreted text can gradually replace the text to be interpreted, in other words, commentary replaces the text (Boone 1989:78-80, referring to Foucault). Although interpretation itself necessarily recasts the texts, the unwillingness to account for this process almost inevitably leads to a cover-up of how interpretation is prejudiced to the "finalisation" of the text. Histories and traditions of interpretation have over many centuries played a more central informative and even formative role in Reformed traditions than what is often admitted. When the accepted or traditional way(s) of interpreting the Bible becomes the only authentic interpretation and effectively replaces the Bible ${ }^{29}$ the interpreted text eventually constitutes the authority (Boone 1989:95).

Along with the importance of stressing the interactive involvement and constitutive role of the reader in the interpretive process, the equally influential role which the interpretive traditions play in the real readers' construction of the text should not be minimised. ${ }^{30}$ Interpretation and generating meaning is the result of an interactive process between reader and text, but never in a neutral way: the text is filtered by and through the reader and the text is best viewed as construction (Segovia 1995c:296, cf 1995a:28-31; 1995b:7-17). A concern with the real readers of the texts within their social contexts - historical, cultural, political, economical and so on - is important, but the emphasis on the reader as social and historical individual, that is, as part of a social and historical community, and therefore accounting for the tradition of interpretation's control over current reading of the text remains equally important.

Not to account for the way in which an established traditional reading or interpretation virtually ostracizes - if then not supplant - the original text, ${ }^{31}$ is to eventually run the risk of uncritically reinterpreting the tradition-embalmed text, that is, interpreting the text without regard and accounting for the tradition and

\footnotetext{
${ }^{29}$ This practice is not restricted to fundamentalist groups; cf e g Goulder (1994:4) "When people have been brought up in a long and unchallenged religious environment, the community's interpretations of its traditions have all the authority of the Bible itself".

${ }^{30}$ Perhaps in reaction to a rigid "history of ideas"-approach, which understood "the early Christian movement ... exclusively in terms of theological positions, conflicts, and developments" (Segovia 1995c:282). Cf Lindbeck's critique of the "cognitivist" model of viewing the history of doctrine as "informative propositions or truth claims about objective realities", and therefore relegates religion to ideas (Meeks 1986:177).

${ }^{31}$ From a religious studies perspective, Bloom (1992:16) senses the actual displacement of the biblical texts when he argues that the traditional notion of Christianity as a "religion of the book" is inaccurate: Christianity is "the religion of the Church Fathers and the Protestant theologians who broke with the Church."
} 
its influence. ${ }^{32}$ What happens particularly in midrash, can probably be found in all interpretation, but is, however, not always consciously recognised as such. "The words of the wise are not added to the text; they are the text as well, linking its words to another form, not an integrated, hierarchical system, but an ongoing tradition, a structure of mutual belonging" (Bruns 1990:202). The text become the palimpsest onto which the interpretation is copied, with the text soon and increasingly fading out of the background position it already assumes. ${ }^{33}$ To put it bluntly, readers soon end up reading their own texts and not the texts which they purport to read (cf Fish, referred to in Boone 1990:65). ${ }^{34}$

Some of these trends can be identified in the current gay-debate in South Africa, as a survey of recent DRC documents and decisions show, underlining the importance of dealing with the reception history of texts and the dangers inherent to its neglect.

\section{SCRIPTURE, THE DUTCH REFORMED CHURCH AND THE GAY-DEBATE}

The realisation that the new South Africa has become part of the global community was brought home by its engagement in a number of glocal debates, ${ }^{35}$ no less the issue of how to deal with homosexuality in the church. ${ }^{36}$

\footnotetext{
${ }^{32}$ Segovia entertains the idea of the text as "construction" as a particular paradigm ("another major development") for the study of the Bible, but reaches his somewhat different conclusion (the readers as constructors of textual meaning vis-à-vis my emphasis on the reception historical framework fitted onto the text), from another direction (the "role" assigned to the text in biblical hermeneutical paradigms). He points to the significance of cultural studies or ideological criticism in biblical hermeneutics where "flesh-and-blood"-readers' activity with regard to the text is taken into account, and all their interpretive attempts are acknowledged as constructions (Segovia 1995a:7, 28-32).

${ }^{33}$ Genette refers to the reworking of texts in different genres and languages as a process similar to the creation of a palimpsest - a new text is written on top of another (or more), previous layer of text, which remains visible to some extent. He refers to his theory as "hypertextuality" and the older layers of text as "hypotexts" (cf Van Zyl-Smit 1996:5). The interpretation or hypertext blurs out the original, to such an extent that the interpreted text displaces the original.

${ }^{34}$ Segovia (1995b:16) concludes with saying that all exegesis is in the end eisegesis.

${ }^{35}$ For an overview of recent official church statements on homosexuality, cf e g Lienemann (1998:7-24), Siker (1994:195-208).

${ }^{36}$ It can also be argued, however, that this debate prominently reflects a search for (a new?) identity in a vastly changed national (although not so much, ecclesial) context, and that a strong heterosexist position inclusive of claims regarding family life and values is more reflective of a last-stand approach amidst vast and fast changes in post-Apartheid S A rather than only a specific socio-ethical model. Cf Smit (2004:147) on the DRC's commitment at its 2002 General Synod to serve South Africa and its people, as well as "the continent and its complex challenges".
} 
The concerted efforts to appropriate Scripture in formulating its position on homosexuality points to - but also beyond - the DRC's protestant-reformed confession, which attaches great (ultimate?) value to biblical authority and normativity. ${ }^{37}$

In a debate often characterised by a dearth of professionalism and even personal integrity, the agreement between the opposing viewpoints seem to be on the importance of using the Bible in ethical decision-making. ${ }^{38}$ However, a different and diverse situation emerges when the recent statements of the DRC about homosexuality are investigated. Although in both the DRC's synodical commission reports as well as in one of its presbytery's legal commission's reports regarding the investigation of a gay minister, there is evidence of academic input, the gay-debate in this church finds itself in a stalemate position, caught up in different hermeneutical paradigms and tied up in a reception history which is not addressed.

\subsection{The DRC's use of the Bible re homosexuality: Two case studies ${ }^{39}$}

The DRC in its official constituencies and reports of various forms and formats consistently claim biblical sanction for the positions and recommendations formulated with regard to homosexuality. In 1986 the DRC's General Synod decided unambiguously against homosexuality in broad terms, claiming this to be "revealed in Scripture", while a contrary position as formulated in the 2002 AKLAS report also claims that the Bible is "conclusive" (Afr deurslaggewend)

\footnotetext{
${ }^{37}$ Along this line, a strong plea was made by a South African theologian of a "sister church" (Nederduitsch Hervormde Kerk) for the two notions of sola fidei and sola Scriptura not to be seen as contrasting or mutually exclusive terms. Faith as the contemporary link and bond between (gay) believer and God should not be overridden by a particular, cultural-bound understanding of Scripture. Wanting to retain the presence of the Bible in contemporary discussions, Dreyer however wavers between the presentation of the biblical material as first century, context-bound instructions or seeing them as matters to be reinterpreted in our (post)modern times (Dreyer 2004:esp 188-191). She applies a more selective hermeneutic which focuses on what constitutes notions of inclusivity in the Bible (Dreyer 2004:esp 199200), and argues that Scripture's rhetorical force is located in announcing God's grace and reconciliation to people (Dreyer 2004:esp 201).

${ }^{38}$ It is widely agreed that a legitimate hermeneutical approach to the six texts typically used for decision making in church on homosexuality should consistently go beyond a narrow, technicist style of identifying a "principle" and rather consider the texts along with their and their interpreters' socio-cultural contexts, allowing also for the "surplus" of meaning of texts (cf Thiselton 2004:145ff, following Gadamer, Betti, Ricoeur and Habermas). But Thiselton does not deal with his social location adequately, allowing the sheer quantitative weight of the traditional opinion and his obvious allegiance to the 1995 St Andrews Day statement to influence him more than he seems to be aware.

${ }^{39}$ Although the rhetorical situation and structure of these documents have to be borne in mind, not expecting them to assume an academic genre, both the AKLAS reports and the Presbytery verdict can be expected to - and indeed do - argue their case with reference to biblical interpretation.
} 
for its own deliberations on this matter - as well as in the more general sense of the word (AKLAS 2002:14.2.4; cf AKLAS 2004:4.7.2.2, esp 1). ${ }^{40}$

\subsubsection{AKLAS ${ }^{41}$ Reports of 2002 and 2004 to the DRC Synods}

The minutes of the 1986 General Synod of the DRC contains its decision that proclaimed the sinfulness of homosexuality. "Homosexual practices and a homosexual relationship must be dismissed for being in contradiction with the will of God, as revealed in Scripture" (General Synod 1986:672; own translation and emphasis added). In contrast to this bold decision, extensive reports of the DRC's AKLAS were tabled at the General Synods in 2002 and 2004, presenting much longer and more detailed arguments while refraining from a strong position on either the unreserved acceptance or rejection of homosexuality and lesbigays, but calling for the withdrawal of the 1986 decision, further theological-ethical study on homosexuality, within the broader context of human sexuality (AKLAS 2002:14.11.1-3; General Synod 2002:12.11), denouncing any form of sexual promiscuity and asking forgiveness for the hurt caused to gay (implicitly, LGBT) people in the past (AKLAS 2004:4.10.1-6 ; General Synod 2004:3.1-7)

Both reports carefully situated their discussions of the relevant texts (LV 18:22; 20:13; Gn 19; Jude 19 and 1 Cor 6:9, 1 Tm 1:10 and Rm 1:26-27) within three broader contexts, namely the reception history of these texts and the enveloping discourse, the biblical, literary context, as well as the contexts of today's modern interpreters. The 2002 AKLAS report dealt with the church's historical struggle to understand homosexuality (14.2) within the context of ethical decision-making (14.3), the difference between Torah as instruction and law (14.4), before dealing with the biblical texts used with reference to homosexuality (14.5) and Romans 1 in particular, on the basis of the argument about what constitutes the natural (14.6). The 2004 AKLAS report built upon the earlier report, but added reflection on the rationale behind the report (4.2), the issues surrounding terminology (4.3), broader biblical patterns (the ministry of Jesus and of the early Christian church) which could assist in interpreting the relevant texts (4.5), and, a social science perspective, focussing on explanations of the origin of homosexuality and arguments regarding the change in sexual orientation (4.6).

\footnotetext{
${ }^{40}$ While space does not allow full discussion of all pertinent and relevant matters in these documents and official decisions, the focus here is on the use of Scripture as it appears in these and other official DRC documents.

${ }^{41}$ AKLAS is the DRC's General Synodical advisory committee for doctrinal matters (Afr Algemene Sinodale Komissie vir Leer en Aktuele Sake).
} 
Responding to the 2004 AKLAS report, the General Synod of 2004 also appealed to Scripture with reference to sexuality, but in such a way that "the message of hope and freedom in Christ" can be "communicated" (Afr tuisgebring kan word). It asked the church's members to assist gays and their families, offered its apology where the church in the past acted inappropriately towards gays, and called for a "biblically founded pastoral model to care for gays". Admitting to different perspectives in this debate, the Synod agreed to further investigation of homosexuality. Heterosexual, monogamous relationships are regarded as the only biblically accepted form of marriage, but that all people regardless of sexual orientation are included in the grace of God. This decision replaced the 1986 decision on homosexuality.

\subsubsection{Presbytery of Cape of Good Hope report 2005 (Gaum-case)}

In April 2005 accusations of (homo)sexual promiscuity were levelled against a DRC minister, Rev L L B Gaum of the St Stephen's church in Cape Town, by his partner who shortly afterwards committed suicide. ${ }^{42}$ The Presbytery of the Cape of Good Hope set its legal commission the task of investigating these accusations, but in the end the focus of investigation shifted to the question of whether a practising homosexual, regardless of the presence of a monogamous, stable relationship, may (continue to) be a minister of religion in the DRC. The general findings (6.1-6.3) of this report were that although no evidence existed for Gaum's alleged promiscuity, he was guilty of being "not honest and open with his church and his congregation" about his monogamous gay relationship. The commission judged this unacceptable, and recommended to St Stephen's church council that Gaum be dismissed as minister of the congregation and his clerical status be suspended. ${ }^{43}$

The report appealed positively to the 2004 decision in denying that homosexual orientation is a punishable sin, but anomalously rejected it in favour of the earlier, 1986 decision of Synod in order to condemn homosexual relationships. ${ }^{44}$ Privileging the 1986 -decision above the 2004 Synod-decision

\footnotetext{
${ }^{42}$ In another event which ensured that the DRC stayed in focus within the gay-debate in S A, the organist of the DRC Moreletapark was dismissed on the grounds that he is gay and lives in a monogamous relationship with his partner for the past 5 years. For a popular report, cf Huisgenoot (2005).

${ }^{43}$ According to newspaper reports, members of the legal commission who took the decision to recommend the suspension of Rev Gaum's ministry at St Stephen's, are quoted as saying that they did not recommend that he be stripped of his ordination and that Rev Gaum would be welcomed back as (gay) minister as soon as he agrees to live celibately (Rapport 2005a).

${ }^{44}$ Even more disconcerting, the report explicitly focuses on sexual acts in its comment that a minister cannot stand in a homosexual sexual relationship (7.3.3.1c; 7.3 refers to an "intimate sexual gay love-relationship"). The report which differentiates between homosexual orientation and homosexual lifestyle (cf 7.2), also seems to insist on a further distinction between sexual and asexual "love-relationships" without accounting for the relation between body and sexuality in the Bible.
} 
is ironic since the latter called for further study on homosexuality and related biblical texts. ${ }^{45}$ However, and importantly, the reference to what is considered the scriptural warrant for one man, one woman marital relationships was used to interpret the rest of the decision of the 2004 Synod $^{46}$ (Presbytery 2005:7.3.3.1 2a) and with that the commission concluded that homosexual relationships per definition falls outside marriage and are promiscuous regardless of whether gays live in a monogamous, nurturing relationship.

The opinion of the Actuaris Synodi (Registrar) of the Western Cape Synod as sought by the legal commission (Presbytery 2005:7.3.6) further elucidated both the influence of a hermeneutical reading grid and the control wielded by the church. His opinion implied that gays are condemned to lives of celibacy since promiscuity is described as any sexual relationship outside of contemporary forms of monogamous, heterosexual marriage and claimed to be forbidden by the Bible. ${ }^{47}$ This particular, if widespread, post-biblical understanding of what constitutes acceptable human sexual relations, structured according to the norm of heterosexuality, seems to override the broader biblical notion of human partnerships where sexuality is lived out within sustained relationships. Rather than allowing for legitimate structures for responsible relationships (including sexual relations), the focus shifted to denouncing a particular form of sexual intercourse. In the end, the actuarius recommended punitive action against Rev Gaum not for his sexual orientation or because of sexual promiscuity, but because his monogamous, faithful relationship was gay and it thus constituted "serious misconduct" when measured against the norm of monogamous, heterosexual marriage.

The heteronormative ideology of the report becomes even clearer when it lists as an aggravating condition that Rev Gaum "appeared as if he had no doubts about his interpretation [of homosexuality]", demonstrating the commission's less than unbiased premise in this regard. In fact, the commission was offended that Rev Gaum's position on the matter "did not

\footnotetext{
${ }^{45}$ An important oversight, however, seems to have been that the 1986 decision was recalled - much debate followed on this point, cf Rapport (2005c). Apart from this and other matters that could make for interesting church-law investigations, the focus is here on hermeneutical considerations of the report.

${ }^{46}$ The claim that the 2004 Synod had no discussions on and made no decision about "'responsible' practical homosexual love-relationships" and that the 1986 Synod's decision therefore stands, leaves out of consideration that the 1986 decision also did not pronounce on this matter specifically - to use a blanket denunciation such as the 1986 Synod's decision is clearly out of step with the 2004 Synod decision.

47 "To deny an entire class of human beings the right peaceably and without harming others to pursue the kind of sexuality that corresponds to their nature is a perversion of the gospel" (Countryman 1999:522), and is the result of self-defined purity codes of contemporary communities of faith and probably not unrelated to a lingering suspicion about the possible moral corruption of sex - often popularly expressed by the notion that "sex is dirty".
} 
consider the merits of the church's interpretation of the scriptural givens and admonition" (Presbytery 2005:8.2.3). This remark of course not only presupposed the veracity of the Church's interpretation ${ }^{48}$ but also disregards the explicit statement in the 2004 Synod decision on different interpretations of Scripture, and the need for more study and discussion on homosexuality (General Synod 2004:3.3, 3.4). In short, the new, authoritative text on gays and homosexuality is not so much Scripture as it is an authorising interpretation in the form of a specific, historic formulation by the DRC. ${ }^{49}$

\subsection{Reception-critical remarks on the DRC's use of the Bible re homosexuality}

These DRC-reports are, in all fairness, quite different in nature and purpose, ${ }^{50}$ and the point here is not primarily to compare them or to adjudicate the validity of their positions, but rather to conclude by making three short reception-critical remarks on the appropriation of the Bible and hermeneutical trends in the new South Africa. ${ }^{51}$ Interestingly, the drafters of the official DRC documents above did not consider it important or feasible to clarify their hermeneutical position, although it is not too difficult to infer their hermeneutical points of departure. ${ }^{52}$ This unfortunately impacts on proper interaction with views expressed whereas it could otherwise have stimulated dialogue by ensuring participants in the debate do not talk pass each other.

\footnotetext{
${ }^{48}$ Apparently this is to be taken as a reference to the 1986 Synod decision; section 8.2.4 mentions "the church's official understanding of the Bible".

${ }^{49}$ Although it is to be remembered that this is a report of a legal commission, the final paragraph is revealing when it expresses the hope that it acted justly and fairly towards Rev Gaum and the DRC, living up to the commission's "church-legal as well as pastoral responsibility" (Presbytery 2005). Here the emphasis shifts from claims about scriptural fidelity to claims about ecclesial loyalty, and references to scriptural imperatives are replaced by the commission's conviction about the validity and therefore authority of (what the commission holds to be) the DRC's interpretation.

${ }^{50}$ The two AKLAS documents were reports made to Synods in contrast to the latter report which served as substantiation of a presbytery's legal position. The point of comparison, though, is (as shown above) that both explicitly claim Scripture as primary point of departure and both provided (some) interpretation of biblical texts in justification of their positions.

${ }^{51}$ Space does not allow an investigation of the (irony of the) real-life reception of the DRC's decisions in the popular media, where some academics are quoted to claim that if the DRC is to allow "gay marriages", it would be tantamount to placing human opinion above the biblical texts or that the DRC would then be a church without the Bible (Rapport 2005b).

${ }^{52}$ In essence, a blend between strategies found in theological interpretation, literary criticism, and in the case of the AKLAS reports also historical-critical insights. Space does not allow the investigation of what seems to be a reliance on a common sense theory of interpretation and its significance for the gay-debate.
} 


\subsubsection{Reception history obliterating the socio-historical context}

The socio-historical context for understanding the three New Testament texts traditionally believed to be related to homosexuality are too easily narrowed down to an intratextual world and populated with modern, contemporary ideas about human bodies and sexuality, relationships and values, conventions and norms. Avoiding ethnocentrism, the socio-historical context of ancient Judaism as well as the Greco-Roman world and their conception of homoeroticism have to be distinguished from our (post)modern world and its notion of homosexuality. ${ }^{53}$

Some crucial aspects of the first-century context to consider when interpreting the NT texts include the complex relationship between sexuality and sex as portrayed in the New Testament. For example, in all he says about marital love, Paul never joins it with sexual relations, and conversely, wherever he discusses sex or marriage, does not mention love (Klassen 1992:384). Marriage is a covenant; there are obligations and responsibilities, but erotic passion in this context seems to be of little interest to Paul. The firstcentury, gendered society rested upon a gender-related superiority versus inferiority, promoted honour and shame as core (motivational) values and gender-determined, and in which power relations revolved around patriarchy. ${ }^{54}$ So for example, the nature argument heard so often in the New Testament rested on a gendered cosmology, which in terms of sexually prescribed active and passive roles, determining roles regarding penetration and, conversely, the particular penetration role determined gender. AKLAS (2002:14.2.4) acknowledges that even if a consensus position regarding biblical condemnation of (modern) homosexuality should be reached, the further problem of relevancy remains, given the clear injunctions against divorce and remarriage which are nevertheless tolerated on the basis of human weakness in the DRC. ${ }^{55}$

On the other hand, the commission's report complete with the actuarius' insistence that "only the love-relationship between one man and one woman can be considered a marriage in biblical sense" (Presbytery 2005:7.3.6), ignores the different forms of marriage found in the Bible, as well

\footnotetext{
${ }^{53}$ In the Dutch context, the GKN-report on homosexuality demanded that OT laws may not be applied without discussion; the message of the whole Bible and its love commandment in particular has to be considered; and, the differences in culture of the biblical authors and the modern readers be considered (Van der Kooij 2001:255-6).

${ }^{54}$ Love in the first-century Mediterranean world was in any case understood as group attachment or bonding (Malina 1993:110-114).

${ }^{55}$ The inconsistency in how scriptural injunctions are considered and implemented is evident, since on the issue of divorce a pragmatic argument is invoked, the choice made is between "worse" or "worst" rather than between "good" or "bad".
} 
as the different ways in which such marriages were contracted and functioned. In the end, a reception history based on a secondary, hermeneutical key incapacitated the legal commission's ability to use the Bible effectively. While the Bible can be enlisted in support of monogamous, heterosexual marriage, the latter cannot simply be imposed as exclusive, interpretative grid for all human, sexual relationships - without the danger of in the process producing a new, authorised or authorising, text.

\subsubsection{The biblical text, reformatted: A new, authorising version}

The important influence of the reception history of texts as well as the need to account for the social location of their readers are not unimportant or negligible given their impact on interpretation but also on the texts. ${ }^{56}$ It was, for example, seen above how the notion of a one woman, one man marital relationship was used as hermeneutical key for interpreting texts referring to homoeroticism in the New Testament, and so became the interpretative norm for determining the implication if not meaning of these texts. The hermeneutical key claimed to be derived from the texts rendered a selfevident reading based upon a form of circular reasoning (reading!). But more devastatingly to the biblical texts, imposing an exclusive, secondary hermeneutical grid on the texts effectively displaces the texts, and effectively replaces the texts as authority. The texts are no longer investigated and researched, but the interpretation which was generated is maintained and defended.

Secondly, the moderature of the DRC and the commission who decided to suspend Gaum in August 2005, appeared to justify this reception history, with reference to the difficulty other mainline churches experienced with determining official policy regarding homosexuality, accepting lesbigays as members and in particular allowing them to occupy clerical positions. The purpose of these appeals probably also intended to register the range of the difficulties as broader than denominational level, and to elicit empathy for the complexity of the decision-making process. The danger with such benchmarking of discussions on homosexuality in the church is that biblical texts are eventually relegated to the common opinion as informed by the force of the reception history of certain texts, or considered hermeneutically

\footnotetext{
${ }^{56}$ When the importance of the context of the interpreter in the form of contemporary, affective encounters and experiences for interpretation is dismissed under the guise of a "biblically based" position (Botha 2005:7) which hints at an ostensible naïve and neutral interpretative stance, questions have to be raised about the interpretative interests of the claimants. The only position more dangerous than a biased hermeneutical stance is the unwillingness or inability to acknowledge it, allowing it to influence interpretation unwittingly and making it very difficult to account for it or to control its influence, and in the end render false notions of neutrality and objectivity!
} 
problematical unless a common interpretation prevails. At the very least, the Bible cannot be claimed as the decisive criterion $^{57}$ if the ecclesial practice of other churches, or the majority opinion, is considered more valuable or even decisive.

\subsubsection{View of Scripture}

As soon as the perception is created that the Bible is a moral-ethical handbook, sometimes in addition to being a catechism of faith, it assumes an oracular status with encyclopaedic value, rather than being the foundational document of Christians, reflecting the earliest believers' faith in and relationship with God. The AKLAS report of 2002 concludes that direct statements of Scripture pertaining to "homosexuality" cannot "summarily" (Afr sondermeer) be seen as binding on people today (AKLAS 2002:14.2.7). It further insists upon the contextualisation of scriptural claims, given the changing nature of the world and advances in scientific knowledge. Rather than invoking literal letters, obedience to God requires the faithful to listen to the Spirit behind the letters - and, one way of achieving this is to constantly place single texts within the context of Scripture's message as a whole (AKLAS 2002:14.3.2). ${ }^{58}$

In the end, it seems in the South African gay-debate that the way(s) in which the Bible is used, might just be more important than the exegesis and interpretation of texts (cf Germond 1997:190) for determining a church's position. The relationship between biblical interpretation, authority and power, and marginality clearly needs more investigation, not only but also because of the particular character and role of biblical interpretation in the DRC during Apartheid in South Africa.

\section{Conclusion}

While a greater openness, unrestricted by government and other authorial influence, now characterises the academy in post-Apartheid South Africa, communities of faith are generally seen to have retreated from the public, socio-political sphere. Churches are at times accused of espousing an internal awareness although they still play an important role in various socio-cultural projects even if no longer at a socio-political level as was the case during

\footnotetext{
${ }^{57}$ The legal commission of the Presbytery (2005:8.2.2) based their decision on "the church's understanding of the biblical information in this regard", making it clear that the Bible is taken as ground for the decision.

${ }^{58}$ The relationship between the Old and New Testaments are considered in the AKLAS report on "Torah versus nomos" (AKLAS 2002:14.4.1-4), invoking the double meaning of the New Testament as $\tau \in \lambda \circ \varsigma$ (end and goal) of the Old.
} 


\section{Using the Bible in post-apartheid South Africa}

Apartheid years (cf Smit 2004). With the Bible serving as the central document of South Africa churches, it is often seen as final court of appeal if not always as point of departure. But with regard to the gay-debate and the complexity and diversity thereof, it is clear that more theological reflection is required on the status and role of the Bible today, on biblical hermeneutics, and on the interstices of biblical reception created by the inevitable crosspollination between the public domains of academy, church and society.

It has probably never been as important as in our postmodern, postApartheid world that hermeneutics cannot be posited as rules, systems or structures of interpretation - as techno-exegesis - but as being open to and indeed listening to the other as other (esp Gadamer, cf Thiselton 2004:146), to reach towards an emancipatory hermeneutics. In the search for truth in the academy, church and society, it is to be remembered in post-Apartheid South Africa also, that "biblical hermeneutic is itself grounded in the moral effect of truth, not merely in truth as a doctrinal formulation" (Anderson 1988:91).

\section{Works consuslted}

Anderson, R S 1988. Towards a theology of a post-apartheid society in South Africa. Journal of Theology for Southern Africa 63, 88-93.

AKLAS DRC 2002. Report: Homosexuality.

AKLAS DRC 2004. Report: Homosexuality.

Bloom, $\mathrm{H}$ 1992. The American religion: The emergence of the post-Christian nation. New York: Simon \& Schuster.

Boone, K C 1989. The Bible tells them so: The discourse of protestant fundamentalism. London: SCM.

Botha, P H 2005. Die Sinode \& homoseks: 'n Kritiese evaluering van die homoseksualiteit debat in die NG Kerk in Suid Afrika. Kranskop: Khanya.

Bruns, G L 1990. The hermeneutics of Midrash, in Schwartz, R M (ed), The book and the text: The Bible and literary criticism, 189-213. London: Basil Blackwell.

Burrows, M S and Rorem, R (eds) 1991. Introduction, in Burrows \& Rorem 1991: xixix.

Burrows, M S and Rorem, P (eds) 1991. Biblical hermeneutics in historical perspective: Studies in honor of Karlfried Froehlich on his sixtieth birthday. Grand Rapids, MI: Eerdmans.

Chilton, B 1995. Traditio-historical criticism and the study of Jesus, in Green 1995:37-60.

Clines, D J A, Fowl, S E \& Porter, S E (eds) 1990. The Bible in three dimensions: Essays in celebrations of forty years of biblical studies in the University of Sheffield. Sheffield: Sheffield Academic Press. (JSOT Suppl Series 87.)

Cloete, G D 2003. Rainbow hermeneutics and St Paul's letter to the Galatians, in Court, J M (ed), Biblical interpretation: The meanings of Scripture - Past and Present, 268-83. London: T\&T Clark.

Coggins, C J \& Houlden, T L (eds) 1990. A dictionary of Biblical interpretation. London: SCM. 
Countryman, L W 1999. New Testament sexual ethics and today's world, in Lebacqz, K (ed) (with D Sinacore-Guinn), Sexuality: A reader, 515-543. Cleveland, OH: Pilgrim Press. (Pilgrim Library of Ethics.)

Dreyer, Y 2004. Homoseksualiteit: Die Kerk, die tradisie en die Bybel - homofobie en sarkofobie en die evangelie. HTS 60, 175-205.

Dube, M W 2000. Postcolonial feminist interpretation of the Bible. St Louis, MO: Chalice.

Froehlich, K 1991a. Church history and the Bible, in Burrows \& Rorem 1991:1-15.

Froehlich, K 1991b. Postscript in Burrows \& Rorem 1991:339-49.

General Synod DRC 1986. Homoseksualiteit: Wat sê die kerk?

General Synod DRC 2002. Besluiteregister. (12.11)

General Synod DRC 2004. Besluiteregister. (3.1-3.7)

Germond, P 1997. Heterosexism, homosexuality and the Bible, in Germond, P and De Gruchy, S (eds), Aliens in the household of God: Homosexuality and Christian faith in South Africa, 188-232. Cape Town: David Philip.

Gottwald, N K 2000. The Bible in South Africa today. Journal of Theology for Southern Africa 108, 91-3.

Goulder, M 1994. A tale of two missions. London: SCM.

Green, J B (ed) 1995. Hearing the New Testament: Strategies for interpretation. Grand Rapids, MI: Eerdmans.

Holub, R C 1984. Reception theory: A critical introduction. London: Methuen. (New Accents.)

Huisgenoot 2005. Nou vat ek julle hof toe! 18 August 2005.

Jauss, H R 1982. Toward an aesthetic of reception, tr by T Bahti, Theory and history of literature, vol 2, Godzich, W \& Schulte-Sasse, J (eds). Brighton: Harvester.

Klassen, W 1992. Love, NT and early Jewish literature, in Freedman, D N (ed), Anchor Bible Dictionary, vol 4, 381-396. New York: DoubleDay.

Lienemann, W 1998. Churches and homosexuality: An overview of recent official church statements on sexual orientation. Ecumenical Review 50(2), 7-21.

Luz, U 1994. Matthew in history: Interpretation, influence, and effects. Minneapolis, MN: Fortress.

Malina, B J 1993. Love, in Pilch, J J \& Malina, B J (eds), Biblical social values and their meaning: A handbook, 110-4. Peabody, MA: Hendrickson.

McKnight, E V 1985. The Bible and the reader: An introduction to literary criticism. Philadelphia, PA: Fortress.

Meeks, W A 1986. A hermeneutics of social embodiment. HTR 79(1-3), 176-86.

Mudimbe, V Y 1988. The invention of Africa; Gnosis, philosophy, and the order of knowledge. Bloomington: Indiana University Press. (African Systems of Thought.)

Naude, P 2005. Can we still hear Paul on the agora? An outsider perspective on South African New Testament scholarship. Paper read at the annual NTSSA meeting, 12-15 April 2005.

Presbytery of Cape of Good Hope (Ringsregskommissie). 2005. Samevattende verslag oor die bevindings en besluite van die ondersoekliggaam t o $v$ die nadelige gerugte rakende Ds L L B Gaum.

Punt, J 1998a. "My Kingdom for a method": South African New Testament scholarship and methodological preoccupation. Neotestamentica 32(1), 135160. 


\section{Using the Bible in post-apartheid South Africa}

Punt, J 1998b. The status of the Bible in Africa: Foundational document or stumbling block? Religion \& Theology 5(3), 265-310.

Räisänen, H 1992. The effective "History" of the Bible: A challenge to biblical scholarship. SJT 45, 303-24.

Rapport 2005a. Kerk het Gaum nié gevra om te verander. 28 August 2005.

Rapport 2005b. NG Kerk nou sonder Bybel, sê teoloog. 4 September 2005.

Rapport 2005c. Sinode "het g'n gay lewe as sonde herroep". 4 September 2005.

Rogerson, R W and Jeanrond, W G 1992. Interpretation, history of, in Freedman, N (ed) Anchor Bible Dictionary, 424-43. New York: Doubleday.

Sawyer, J F A 1990. Interpretation, history of, in Coggins, T J \& Houlden, J L (eds), 316-20. London: SCM.

Schneiders, S M 1989. Feminist ideology criticism and biblical hermeneutics. BTB 19(1), 3-10.

Schneiders, S M 1991. The revelatory rext: Interpreting the New Testament as sacred scripture. San Francisco, CA: HarperSanFrancisco.

Schüssler F E. 1999. Rhetoric and ethic: The politics of biblical studies. Minneapolis, $\mathrm{MN}$ : Fortress.

Segovia, F F 1995a. And they began to speak in other tongues: Competing modes of discourse in contemporary biblical criticism, in Segovia, F F \& Tolbert, M A (eds), Reading from this place, Vol. 1: Social location and biblical interpretation in the United States, 1-32. Minneapolis, MA: Fortress.

Segovia, F F 1995b. Cultural studies and contemporary biblical criticism: Ideological criticism as mode of discourse, in Segovia, F F \& Tolbert, M A (eds), Reading from this place, vol 2: Social location and biblical interpretation in global perspective, 1-17. Minneapolis, MN: Fortress.

Segovia, F F 1995c. The text as other: Towards a Hispanic American hermeneutic, in Smith-Christopher, D (ed), Text \& experience: Towards a cultural exegesis of the Bible, 276-98. Sheffield: Sheffield Academic Press.

Siker, J S (ed) 1994. Homosexuality in the Church: Both sides of the debate. Louisville, KY: Westminster John Knox.

Smit, D J 2004. The impact of the church in South Africa after the collapse of the apartheid regime, in Bediako, $\mathrm{K}$ (eds) et al, A new day dawning: African Christians living the Gospel: Essays in honour of Dr J J (Hans) Visser, 12849. Zoetermeer: Uitgeverij Boekencentrum.

Stone, K 1997. The hermeneutics of abomination: On gay men, Canaanites, and biblical interpretation. Biblical Theology Bulletin 27(2), 36-41.

Tatchell, P 2000 [cited 13/01/2005]. 2000 Years of church homophobia. Available from www.petertatchell.net/religion/2000.htm.

Thiselton, A C 2004. Can hermeneutics ease the deadlock? Some biblical exegesis and hermeneutical models, in Bradshaw, T (ed), The way forward? Christian voices on homosexuality and the church, 145-96. $2^{\text {nd }}$ ed. Grand Rapids, MI: Eerdmans.

Van der Kooij, A 2001. Bible exegesis in Dutch ecclesial documents of homosexuality. Scriptura 77, 252-7.

Van Zyl-Smit, B 1996. Gyges and Kandaules in ancient and modern literature. Akroterion 41(1-2), 5-21.

Vorster, W 1983. The Bible and Apartheid 1, in De Gruchy, J W \& Villa-Vicencio, C (eds), Apartheid is a heresy, 94-111. Cape Town: David Philip, Lutterworth. 
Vorster, J N 1997. The body as strategy of power in religious discourse. Neotestamentica 31(2), 389-411.

West, G O 1991. Biblical hermeneutics of liberation: Modes of reading the Bible in the South African context. Pietermaritzburg: Cluster Publications. (Cluster Monograph Series, vol 1.)

West, G O 2004. The open and closed Bible: The Bible in African theologies, in Conradie, E M (ed), African Christian Theologies in Transformation, 162-180. Cape Town: EFSA.

Zack, N (ed) 1997. Race/Sex: Their sameness, difference, and interplay. New York: Routledge. 